\title{
Corporate Governance And Banks Profitability In Nigeria
}

\author{
G. O. Demaki, Ph.D. \\ Department of Business Administration \\ Delta State University, Abraka
}

\begin{abstract}
This paper is the report of a research undertaking which empirically evaluated the influence of corporate governance on the profit of banks. The research design is a case study of seven (7) DMBs in Nigeria. The materials and methods includes collection of secondary data from purposely selected annual report and accounts of seen (7) DMBs published in Nigeria Stock Exchange (NSE) Factbook with the requisite data, namely; First Bank of Nigeria (FBN), Access Bank, Diamond Bank, Guarantee Trust (GT) Bank, Sterling Bank, UBA and Zenith Bank respectively, covering a period between 2008 2014. The Nigerian 2011 Securities and Exchange Commission (SEC) Corporate Governance Code provisions which were the independent variables in this study includes Board Composition (BCOMP), Directors Remuneration (DRM), Board Committee (BDCOMT) Audit Composition (ADCOMP) respectively. Banksize and age were the intervening variables. The transactional cost theory forms the theoretical framework of the investigation. The Net Profit After Tax (NPAT) of the sample banks was the dependent variable and profitability proxy of the study. The method of estimation includes descriptive statistics, analysis of correlation matrix and ordinary least square techniques together with model specification. Findings from the evaluation of the slope-coefficients of independent variables (i.e. BCOMP, DRM, BCOMT and ADCOMP) reveals the existence of positive relationship between these variables inter-alia and profitability of the sample banks. Although, Directors Remuneration (DRM) and Board Committee (BCOMT) appears to exert a negative relationship with banks profitability but which were not statistically significant at $5 \%$ level. In conclusion, the new draft code of corporate governance absolute mandatory mechanism embedded into it should be enforceable in Nigeria without further delay to strengthen the success of the existing 2011 SEC Code of Corporate Governance Code in Nigeria.
\end{abstract}

Keywords: 2011 SEC Code, Deposit Money Banks, Board Composition, Board Committee, Directors Remuneration, Audit Composition, Net Profit After Tax

\section{INTRODUCTION}

The increasing incidence of corporate fraud relating to exaggerated and overstated accounts have informed the renewed global emphasis on the need for effective corporate governance. Other companies in default of corporate governance include ARTHUR ANDERSON \& CO, MG. INTERNATIONAL GROUP, LEHMAN BROTHERS LTD, NORTHERNROCK (Rescued and nationalized by the British Government) among others. According to Ezeako (2016), Nigerian companies were also in default of adherence to good corporate governance.. Financial overstatements were uncovered in Cadbury (Nig) Plc during a due diligence exercise conducted by Scheweppes Plc, a major shareholder, in its effort to increase its investments in Cadbury (Nig) Plc from 46\% to 50\%. Ajayi (2006) disclosed further that the investigation revealed that there was deliberate overstatement by Cadbury (Nig) Plc financial position over a number of years to the tune of between $\$ 13$ and $\$ 15$ billion. Alfaki (2007) against this backdrop, discloses that international agencies like the International Organization of Securities Commission (IOSCO), Federation of International de Boors deovaldes (FIBV), the World Bank and the organization for Economic Corporate and Development (OECD) are all in the vanguard of setting good corporate governance worldwide. He maintains that corporate governance 
largely came to the centre of international development agenda following the East Asian financial crisis. The crisis had some painful social and economic consequences which prompted an urgent analysis as to its origin. Faulty corporate governance in the financial system was a major culprit. As a result, adherence to good corporate governance is currently recognized as crucial in success, growth and development of the corporate sector. Many countries including Nigeria are putting in place various measures to strengthen good corporate governance in order to tackle the problems connected with bad corporate governance practices. The purpose of introducing corporate governance code is to help sustain investors' confidence and serve as a benchmark for monitoring and implementing corporate policies and practices at firm level.

The truth is that foreign investors will only be interested in investing in a well run company. Corporate governance codes and the regulatory framework must be interlinked with global business environment and continuously modernized in line with local circumstances since regulators, institutional investors and a probing media are still weak in Nigeria.

To strengthen the corporate governance code in Nigeria, Section 60-65 of the Investment and Securities Act (ISA) 2007 provisions are contained in the 2003 and 2011 SEC code respectively. The inclusion has made it mandatory for operators and public quoted companies to file with the commission on a periodic or annual basis, its audited financial statements and such other Returns as may be prescribed by the commission from time to time (ISA sec 60(i) ). A public company shall establish a system of internal control over its asset and shall be the responsibility of the board of directors to ensure the integrity of the company's financial control and reporting (ISA Sec 61(i) ).

It is important to emphasize that incidences of corporate governance failure among reputable multinational corporations, the great financial crisis (financial downturn), including capital market stagnation in both developed and developing economies together with the various legislations and measures that nations are putting in place globally to tackle bad or poor corporate governance practices may have been responsible for the 2003 and 2011 SEC code of corporate governance and regulatory framework reforms in Nigeria.

This study seeks to evaluate the code of corporate governance on banks profitability in Nigeria from 2008 to 2014 using the 2011 Securities and Exchange Commission (SEC) Code of Corporate Governance as a benchmark.

\section{Objectives of the Study}

The main objective of the research is to evaluate the effect of the 2011 SEC Code of Corporate Governance on banks profitability in Nigeria.

The specific objectives include:

i. Examine the relationship between Board Composition (i.e. BCOMP) and Net Profit After Tax (NPAT) of DMBs in Nigeria.

ii. Assess the effect of Board Committee (i.e. BCOMT) on NPAT of DMBs in Nigeria.

iii. Determine the influence of Audit Composition (ADCOMP) on NPAT of DMBs in Nigeria.

iv. Appraise the relationship between Directors Remuneration (DRM) and Net Profit After Tax (NPAT) of DMBs in Nigeria.

The rest of this report is organized as follows: section 2 is the definition of terms, the review of related literature and theoretical framework. Section 3 deals with materials and methods 
together with model specification. Section 4 is data presentation and analysis, while section 5 is conclusion and recommendations.

\section{DEFINITION OF TERMS, REVIEW OF RELATED LITERATURE AND THEORETICAL FRAMEWORK}

The definition of concepts, related literatures that were reviewed in this study together with the theoretical foundation on which the investigation is rooted are stated purposely hereunder to achieve some measure of clarity.

\section{Corporate Governance}

It is defined in this study as "a system of law and sound approaches by which corporations are directed and controlled focussing on the internal and external corporate structures with the intention of monitoring the actions of management and directors and thereby mitigating agency risks which may stem from the misdeed of corporate officer" (Wikipedia Encyclopaedia, 2013). Corporate governance in this study specifically also includes regulatory provisions of the 2011 Securities and Exchange Commission (SEC) Code of Corporate Governance which comprise of Board Composition (BCOMP), Directors Remunerations (DRM), Board Committee (BCOMPT) and Audit Composition (ADCOMP).

\section{Banks Profitability}

It is defined, for the purpose of the study, as the Net Profit After Tax (NPAT) derived from Annual Reports and Account of the Sample Deposit Money Banks which are publicly quoted on the floor of the Nigerian Stock Exchange (NSE) from 2008-2014.

\section{Review of Related Literatures}

Nigerian companies, especially banks in the financial sector, suffered from poor performance and the market capitalization of the Nigerian Stock Exchange (NSE) also diminished from \$80.6 billion in 2008 to $\$ 47.75$ billion in 2009 .

There was massive fall in share prices as a result of insider trading in the capital market and manipulation of financial results of companies. A notable incident was that of Cadbury Nigeria Plc. The Securities and Exchange Commission (SEC) had to conduct an investigation into allegation of overstatement of earnings to the tune of N13.25 billion. Also from 2007, fraud and corruption were uncovered in major Nigerian companies leading to the sack of key senior management staff of the Nigerian Stock Exchange (NSE).

Poor corporate governance among corporations co-exists with loss of integrity and incidence of high corruption is an impediment for inflow of international capital which leads to regional financial crisis triggered by the collapse of domestic currency. Corporate governance is a part of the macro economic system of accounting and as such it cannot succeed in the absence of corresponding macroeconomic and public reforms. Business needs free environment and strong legal system to flourish. The global economic downturn and the crisis in the banking and other sectors in Nigeria are manifestation of poor corporate governance. Succeeding in the modern day environment of conducting business and consolidating such gains requires government institutions as well as business organizations to assimilate the culture of sound corporate governance principles.

Many business failures in the past and in recent times have been associated with poor corporate governance practices. This often results in poor vision, misplacement of priorities, inefficiencies, demotivation, declining moral, redundancies, declining profitability, apathy and insecurity of investors' funds. 
Anecdotal and formal empirical studies attempted to provide a link between poor corporate governance and business failures. Poor corporate governance was identified as one of the primary causes of all known incidence of distress in the Nigerian banking industry and that was why the Central Bank of Nigeria (CBN) issued the CBN code of corporate governance for banks in Nigeria in 2006 and subsequently as 2012 CBN Code of corporate governance to check corporate governance abuses and professional misconduct by the board, management and staff of banks. The 2006 and 2012 CBN Code of Corporate Governance was designed to bring sanity to the banking governance practices and operation. The period 2005-2009 was characterized by unprecedented financial crises both in Nigeria and around the globe.

There is also international competition to attract foreign investors in a globalized world. Nigeria requires foreign capital for development. It cannot afford to isolate itself due to poor country-level and firm-level corporate governance practices.

Shareholders are mobile. Missing out from international development due to poor corporate governance implies double danger. First, Nigeria loses ground in the global competition for international investor's money. Secondly, Nigeria is already loosing domestic investors attracted by other capital markets. Nigeria Stock market is weak and has been stagnated in the last 13 years, while markets around the world with effective corporate governance are growing strongly.

Evidence abounds from the Nigeria capital market (NCM) report, 2009, which ranked Nigeria below South Africa and Kenya with corresponding losses of $25.72 \%$ and $31.33 \%$ respectively. The report further added that other nations such as Ghana, Tanzania and Tunisia maintained marginal gains of $40.68 \%, 21 \%$ and $10.65 \%$ respectively occasioned from their level of exposure to and strict adherence to international code of best practices in corporate governance. The forensic audit on the four years financial statement of the Nigerian Stock Exchange (NSE) by Akintola William Delliote, as directed by SEC, showed that NSE limited by guarantee was not allowed to declare surplus as bonus to its council members contrary to Section 26 (3) of the Companies and Allied Matters Act Cap C20 LFN 2004 and Section 6 of the memorandum and Articles of Association of the Exchange which states that it shall be applied solely towards the promotion of the objective of the exchange and no portion thereof shall be paid or transferred directly or indirectly by way of dividend, bonus or otherwise. The summary of the illegally shared money in violation of sound governance principles amounted to N2.050 trillion between 2006-2009 culminating in the dissolution of NSE governing Council (Egwatu, 2010).

Further still, is the fact that government regulators, including the SEC that are in breach of sound corporate governance principles $\backslash$ are also to be blamed for the capital market crisis. The administrative arrangement whereby $0.3 \%$ was collected by SEC from everybody that sells shares and every company that goes to the capital market, including stockbrokers and investors, was illegal and in violation of sound corporate governance principles. Such money was never remitted to the Federation account nor disclosed in SEC financial report. There was no provision in the ISA 2007 and the Companies and Allied Matters Act (CAMA) 1990 that authorized SEC to collect money $(0.3 \%)$ from market operators even though government failed to fund it as a regulatory body. Such illegal collection of money from market operators compromised the regulatory function of the commission. SEC requires $100 \%$ funding by government to police the capital market properly without been an appendage of the powerful capital market operators (Okereke-Onyiuke, 2012). Transparency International (2003) and Bayagbon (2015) ranked Nigeria among the most corrupt nations in the world occupying 
second position after Bangladesh. Records have also shown that efforts made by the past regimes to re-engineer the financial sector of the economy have proved abortive as the envisaged bounded rationality of transactional cost theory failed to bring about much needed transformation in business operations.

However, some companies in the communication and oil sectors maintain their performance and stabilize their market prices (NCMR Report 2009). Therefore, the question that leaps to mind is that could the above phenomena be attributed to the displacement of bounded rationality by opportunism? How can mandatory regulatory mechanism of 2011 SEC Code of corporate governance prevent displacement of bounded rationality by opportunism? How will the 2011 SEC Code of Corporate Governance influence profitability of companies, including banks.

Given the above problem, this study is designed to evaluate the influence of corporate governance on banks profitability in Nigeria.

\section{Theoretical Framework: The Modified Transactional Cost Theory (MTCT)}

The original cost theory presupposes that an organization consists of individuals with diverse perception and objectives rather than an economic entity perpetually in a state of perfect market equilibrium. Furthermore, in this proposition, is the argument that price movement outside the companies or organization direct production process may be a major challenge to management but the market for the sale of products or services can influence forces externally imposed in the industry. The theory posit further that while companies become so large and complex, they can substitute for market in determining the allocation of resource (Cybert and March, 1963 and Akata, 2017). The implication of this is that how a firm is organized determines its control over what transactions. The extent of internalization of organization transaction determines the degree of risks and uncertainty around its products, prices, quality and brand loyalty in the market place. The central tendency of the transactional cost theory (TCT) project the human as realist and that managers and directors as agents practice bounded rationality (i.e. self-restraints).

The theory (TCT) presumes managers organize transactions so as to economize resources and maximize return on investment based on bounded rationality while simultaneously safeguarding the transactions in questions against hazard of opportunism.

However, the modified transactional cost theory differ from transactional cost theory insisting that the original transactional cost theory is an oversimplification of reality. The modified transactional cost theory is a hypothetical construct of this researcher. The non-recognition of the consequences of the displacement of bounded rationality by hazardous opportunism in actual business transaction which may include exposure $f$ the company, firm or organization to serious damaging consequences eroding their resources and values which in turn give rise to wastages, poor performance and capital flight by investors is a major limitation of the original transactional cost theory.

Demaki (2017) research findings reveals displacement of bounded, rationality by hazardous opportunism manifested among many Nigerian banks namely; Bank PHB Plc, Afribank Plc, Oceanic International Bank Plc, Spring Bank Plc, which was responsible for their aggregated toxic asset amounting to over N2 trillion. The modified transactional cost theory is predicated on the assumption that some of the mandatory regulatory mechanism system in the provision of the 2011 SEC Code of Corporate Governance constitutes a regulatory framework in regulating firm and companies operation and prevent the displacement of bounded rationality 
by hazardous opportunism among companies including banks.

\section{MATERIALS AND METHODS}

In this study, data were obtained from the Annual Reports and Accounts of seven sample banks in Nigeria. Corporate governance variables used in this paper were selected from the specifications of the 2011 Codes of Corporate Governance for Public Companies in Nigeria and includes Board Composition, Directors Remuneration, Board Committee and Audit Committee Composition. In addition to these, two (2) intervening variables namely: Firm Size and Age of Firm were introduced in the model. The dependent variable used in this study to capture banks profitability is Net Profit after Tax. A quantitative analysis was conducted based on the data obtained using the Ordinary Least Square (OLS) estimation technique. The model specification is given as:

$$
\begin{aligned}
\text { NPAT } & =\mathbf{F}(\text { BDCOMP, BDCOMT, ADCOMP, DRM, FSIZE, AGE) .. eq. } 1 \\
& =\beta_{0}+\beta_{1} \text { BDCOMP }_{t}+\beta_{2} \text { BDCOMT }_{t}+\beta_{3} \text { ADCOMP }_{t}+\beta_{4} \text { DRM }_{t} . . \text { eq. } 2
\end{aligned}
$$

Where:

NPAT $=$ Net Profit after Tax (proxy for Profitability)

BDCOMP = Board Composition

ADCOMT $=$ Audit Composition

BDCOMT $=$ Board Committee

DRM $=$ Directors Remuneration

FS1ZE = Firm Size (Total Assets)

AGE $=$ Age of Firm (Number of years in business)

$\mathrm{U}_{\mathrm{t}}=$ Error Term

$\mathrm{T}=$ Periods

The period under investigation is 2008 -2014. A pooled regression was done for the period 2008-2014.

\section{Analysis of Data}

\section{DATA PRESENTATION AND ANALYSIS}

The analysis of data was presented in order of priority: descriptive statistics, correlation matrix, regression and chow test results.

\section{The Analysis of Descriptive Statistics}

The analysis of descriptive statistics which involves the mean, standard deviation, minimum and maximum values were presented and analyzed.

Table 1: Descriptive Statistics

\begin{tabular}{lllcc}
\hline Variables & Mean & Std. Dev. & Min. Value & Max. Value \\
\hline NPAT & 17675191.8 & 30802514.6 & 0 & $151,121,704$ \\
BRDCOMP & 12.7755 & 2.60020 & 9 & 20 \\
BRDCOMT & 9.3469 & 2.82512 & 5 & 14 \\
ADCOMP & 6.1429 & .35355 & 6 & 7 \\
DREM & 177371.1 & 183993.4 & 2,876 & 465008 \\
FSIZE & 574267076.2 & 695901227.5 & $465,210.9$ & $1,680,302,005$ \\
AGE & 39.3469 & 33.15152 & 18 & 121 \\
IFRSDUM & .5714 & .50000 & 3 & 3 \\
\hline
\end{tabular}

Source: Regression Output, 2015 
Table 1 presents the descriptive statistics results for the dependent variable (Net profit after tax) and independent variables (board composition, board committee, audit committee, directors remuneration, firm size and age of firm). As observed, the mean for NPAT is positive with a high standard deviation, a suggestion that sampled banks highly complied with IFRS provisions. The minimum and maximum values are 0 and N151,121,704 respectively. The zero minimum value is suggestive of the fact that some banks did not report values for certain period. However the maximum NPAT was reported by FCMB in 2012. The mean for Board Composition (BDCOMP) is approximately 13 with minimum and maximum values of 9 and 20 respectively. The standard deviation of 2.60 indicates that the board composition for most banks in the sample may not deviate significantly from the mean board composition.

The mean for Board Committee (BDCOMT) is approximately 9 with maximum and minimum values of 5 and 7 respectively. The standard deviation of 2.80 which indicates that the board committee for most banks in the sample may not deviate significantly from the mean board committee. Furthermore, Audit Committee Composition (ADCOMP) had a mean value of 6.14 and a standard deviation is 0.35355. The minimum and maximum values are 6 and 7 respectively. The implication of this is that audit committee composition of the sampled banks is revolved around the mean. Also, the mean value of Directors Remuneration (DRM) $\$ 177,371.1$, standard deviation of $\$ 183,993.4$ and the minimum and maximum values are $\$ 2,876$ and $\$ 465,008$ respectively. The high mean and standard deviation recorded was due to the fact that directors were adequately remunerated, an indication that the governance code on directors remuneration was adequately complied with. This is because the Code of Corporate Governance stipulates categorically that directors (executive and non-executive directors) should be adequately remunerated. Firm Size (FZIE) has a mean value of $\$ 574,267,076.2$ with minimum and maximum values of $\$ 465,2109$ and $\$ 1,680,302,005$ respectively. The Age of the bank was measured by the number of periods banks have been in business. The mean and standard deviation values for the age of bank are 39 years and 33years respectively. The minimum and maximum values were 18 years and 121 years

\section{Analysis of Correlation Matrix}

Table2: Analysis of Correlation Matrix

\begin{tabular}{lllllllll}
\hline Variables & NPAT & FSIZE & BDCOMP & DRM & BCOMT & ADCOMT & AGE & IFRSDUM \\
\hline NPAT97 & 1.000 & .708 & .376 & .252 & .386 & -.129 & -.183 & .272 \\
FSIZE1.000 & .708 & 1.000 & .309 & .221 & .399 & -.197 & -.303 & .299 \\
BDCOMP & .376 & .309 & 1.000 & .597 & .788 & -.123 & -.487 & .021 \\
DRM & .252 & .221 & .597 & 1.000 & .140 & .555 & -.314 & -.009 \\
BCOMT & .386 & .399 & .788 & .140 & 1.000 & -.635 & -.227 & .019 \\
ADCOMP & -.129 & -.197 & 0.123 & .555 & -.635 & 1.000 & -.216 & .000 \\
AGE & 0.183 & -.303 & -.487 & -.314 & -.227 & -.216 & 1.000 & .028 \\
IFRSDUM & .272 & .299 & .021 & -.009 & .019 & .000 & .028 & 1.000 \\
\hline
\end{tabular}

Source: Regression Output, 2015

The table above presents the correlation matrix of the dependent, independent and intervening variables. The Pearson's correlation matrix shows the degree of correlation between the independent variables which is either low or moderate, thus suggests the absence of multicollinearity between the variables. As suggested by Van, Shahnaz and Nurasyikin (2008), the Pearson's $R$ between each pair of independent variables should not exceed 0.80; otherwise, independent variables with a coefficient in excess of 0.80 may be suspected of exhibiting multicollinearity. The highest correlation as disclosed in the table is between Board Committee (BCOMT) and Board Composition (BDCOMP) with value of .788. This confirms that 
there is no multicollinearity among the variable.

Analysis of Regression Results

\begin{tabular}{|c|c|c|c|c|}
\hline \multicolumn{5}{|c|}{ Table 3: Goodness of Fit Tests } \\
\hline Model & $\mathbf{R}$ & $\begin{array}{c}\mathbf{R} \\
\text { Square }\end{array}$ & $\begin{array}{l}\text { Adjusted R } \\
\text { Square }\end{array}$ & $\begin{array}{c}\text { Std. Error of the } \\
\text { Estimate }\end{array}$ \\
\hline 1 & $.748^{a}$ & .559 & .484 & 22136148.43132 \\
\hline
\end{tabular}

a. Predictors: (Constant), BDCOMP, BDCOMT, ADCOMP, DRM, FSIZE, AGE, IFRSDUM

As shown in Table 3 above, both $\mathrm{R}^{2}$ and adjusted $\mathrm{R}^{2}$ measure the fitness of the model i.e. they measure the proportion of the variation in dependent variable explained by the model. But since adjusted $R^{2}$ is the modification for the limitation of $R^{2}$ the value of the adjusted $R^{2}$ is considered to measure the fitness of the model. Thus, as it is shown above, the value of adjusted $\mathrm{R}^{2}$ is 484 , indicating that the independent variables in the model are explaining $48 \%$ variation on the dependent variables while the unexplained variation is $52 \%$. Thus, we can understand that the model of the study is not providing a good fit to the data.

Dependent Variable: NPAT

Table 4: Regression Result

Sample: 2008-2014

Periods included: 7

Cross-sections included: 7

Total observations: 49

White cross-section standard errors \& cocariance (d.f. corrected)

\begin{tabular}{|c|c|c|c|c|}
\hline Variable & Coefficient & Std. Error & T-Statistics & Prob. \\
\hline C & -181263573.5 & 176685566.7 & -1.026 & .311 \\
\hline FSIZE & .033 & .006 & 5.095 & .000 \\
\hline BDCOMP & 5619451.8 & 4303562.9 & 1.306 & .199 \\
\hline DRM & -38.610 & 44.037 & -.877 & .386 \\
\hline ВСОMT & -728675.7 & 4035531.6 & -.181 & .858 \\
\hline ADCOMP & 18298716.8 & 25524718.8 & .717 & .477 \\
\hline AGE & 213297.5 & 143652.7 & 1.485 & .145 \\
\hline IFRSDUM & 2077865.4 & 7064449.9 & .294 & .770 \\
\hline R-square & .559 & \multicolumn{2}{|c|}{ Mean dependent var } & 17675191.8 \\
\hline $\begin{array}{l}\text { Adjusted R- } \\
\text { square }\end{array}$ & .484 & \multicolumn{2}{|c|}{ S.D. dependent var } & 23027060.0 \\
\hline $\begin{array}{ll}\text { S.E. } & \text { of } \\
\text { regression }\end{array}$ & 22136148.4 & \multicolumn{2}{|c|}{ Sum squared resid } & .894 \\
\hline F-Statistics & 7.420 & \multicolumn{2}{|c|}{ Durbin-Watson stat } & 2.079 \\
\hline
\end{tabular}

Source: Regression Output, 2015

The evaluation of the slope coefficients of the explanatory variable (Firm Size, Board Composition, Audit Committee, Age of Firm) reveals the existence of positive relationship between these variables inter-alia and profitability (Net profit after tax) as depicted by the slope coefficient of .033, 5619451.8, 18298716.8, and 213297.5 respectively. Director's remuneration (DRM), Board Committee (BDCOMT) appears to exert a negative relationship with profitability which is not also statistically significant at $5 \%$ level. 


\section{CONCLUSION AND RECOMMENDATIONS}

The study set out with the main objective of finding out the influence of the 2011 SEC Code of Corporate Governance on the profitability of Deposit Money Banks (DMBs) in Nigeria. Four specific objectives were also investigated. The result from the evaluation of the slope coefficients of the independent variables (i.e. Board Composition), (BCOMP), Director's Remuneration (DRM), Board Committee (BCOMT) and Audit Composition (ADCOMP) shows the existence of positive relationship between these variables inter-alia and profitability of the sample DMBs. Although Directors Remuneration (DRM) and Board Composition (BCOMT) exert a negative relationship with DMBs profitability perhaps due to hazardous opportunism among the sample DMBs but were not statistically significant at 5\% level.

The new draft Code of Corporate Governance with absolute mandatory mechanism embedded into it should be enforceable in Nigeria without further delay. The comply-or-explain system without sanction attached in the 2003 SEC Code of Corporate Governance was responsible for the poor corporate governance practice among banks in Nigeria. The mandatory new draft code of corporate governance will strengthen the success of the existing 2011 SEC Code of Corporate Governance. Nigeria can copiously explain default in compliance with corporate governance provisions that will even overwhelm the regulators. Mandatory mechanisms in the new draft will prevent the displacement of bounded rationality among business managers by the innate hazardous opportunism of human beings.

According to Ofo (2016), in other jurisdiction where comply-or-explain corporate governance system exists, the legal and judicial framework are working excellently unlike in Nigeria where individuals who commit offence for corporate governance infractions go to court to stop regulatory enforcement agents from even investigating the offence committed.

\section{References}

Ajayi B. (2006). Cadbury: Nigeria's Enron Retrieves. April 8, 2013, from Nigeriaworld:nigeriaworld.com Akata, G. 0. (2017). Corporate Governance: An Emerging Economy Perspective. Ibadan: University Press Ltd. Bayagbon, M. (2015). Fighting One Corruption. Vanguard. 25 (62411) p. 18.

Cyert, R. M. and March, J. G. (1963). A. Behavioural Theory of the Firm, Englewood Cliffs, N.J.: Prentice Hall.

Demaki, G. O. (2017). 2011 Securities and Exchange Commission Code of Corporate Governance and Performance of Deposit Money Banks in Nigeria. Journal of Economics, Management and Trade. 18 (3): 1-11.

Egwatu, P. (2010). Bonus Sharing: How NSE May Have Defied Corporate Governance. Financial Vanguard. 25 (61226). www.vanguardngr.com

Ezeaku, N. (2016). Corporate Governance: The Responsibility of All Members of the Board of Directors. The Chartered Secretary and Administrators. Journal of the Institute of Chartered Secretaries and Administrators of Nigeria. 12 (23). P 10-20.

NCM Report (2009). Nigerian Capital Market Report. Proshareng.com

Ofo, N. (2016). Institute of Chartered Secretaries and Administrators of Nigeria. (ICSAN) is the Leading Authority on Corporate Governance. The Chartered Secretary and Administrator. Journal of the Institute of Chartered Secretaries and Administrators of Nigeria. 12 (23) p.23-30.

Okereke-onyuike, N. (2012). Blame Government Regulators for Capital Market Crisis. In Anikulapo (Ed). The Guardian. 29 (12190). www.ngrguardiannews.com

Van, Z. W.A. Shahna,I. and Nurasyik, J. (2008). The Impact of Board Composition, Ownership and CEO Duality on Audit Quality. Malaysian Accounting Review. 7 (2). P.1-22.

Wikipedia (2013). Governance. Retrieved March 28, 2013. From Wikipedia:en. wikipedia.org/wiki/governance www.google.com www.wikipedia.com 